\title{
MODEL PENGEMBANGAN DAN PEMANFAATAN WAKAF TUNAI UNTUK PENDIDIKAN TINGGI (STUDI KASUS WAKAF AMERTA AIRLANGGA)
}

\author{
Muhamad Syadid \\ Muhammad Arfan Muammar \\ Universitas Muhammadiyah Surabaya \\ Email: sadidwakaf@gmail.com
}

\begin{abstract}
The The increasingly difficult economic conditions require educational institutions at the tertiary level to develop a model for collecting funds from the community, one of which is through cash waqf. Airlangga University already has a model of developing and utilizing campus-based cash waqf. So with this waqf solution the community can be helped especially by students to continue their education. From here the authors are encouraged to conduct research on "Models of Development and Utilization of Cash Waqf for Higher Education (Case Study of Waqf Amerta Airlangga.".

With the formulation of the problem: first, How to use cash waqf for higher education in Amerta Airlangga Waqf. Second, how to model the development of cash waqf in Amerta Airlangga. The method of this study used qualitative-descriptive because the data was qualitative, the data was not quantitative which used statistic. Practically, the data collection used three methods, they were: interview, observation, and documentation.

Based on the results of research in Waqf Amerta Airlangga, it is known that the Community donated funds to the Waqf Amerta Airlangga through PUSPAS which is divided into two types, namely non-endowment social donations and endowment donations. Then some of the non-waqf funds were directly put into social donation accounts which could be directly utilized for the Airlangga University PUSPAS program, by $85 \%$. While the other $15 \%$ is for the operations of PUSPAS Airlangga University. The Waqf Fund through the Amerta Endowments program will be managed separately for the fund as an investment in a number of portfolios.
\end{abstract}

Key Words : Development and Utilization Model, Cash Waqf, Higher Education

\section{A. PENDAHULUAN}

Dalam konstelasi ekonomi Indonesia, wakaf tunai adalah instrumen yang masih dianggap baru. Bahasan tentang wakaf tunai di Indonesia mulai menguak setelah ekonom muslim asal Bangladesh, Prof. M. A. Mannan, menggagasnya. Dengan karakteristiknya yang melekat, wakaf uang memiliki keunggulan dalam memobilisasi dana wakaf lebih cepat dibanding wakaf benda kongkrit. Meski nilai uang berkurang setiap waktu karena tergerus inflasi, tapi sifatnya yang fleksibel menjadikan wakaf uang dapat menjadi instrumen bagi mekanisme kontraksi likuiditas.

Selain akadtijarah, fiqh muamalah juga mengenal akad tabarru' yang dapat menjadi alternatif kebijakan pemerintah dalam membangun 
kehidupan sosial ekonomi masyarakat. Sebagai salah satu instrumen keuangan Islam berbasis akad tabarru', wakaf tidak hanya unggul dalam mengatasi berbagai persoalan sosial, tetapi juga unggul dalam mengelola likuiditas perekonomian. Ekses likuiditas perekonomian dapat diatasi salah satunya dengan akad tabarru'. Dalam konteks ini, wakaf dapat mengambil peran sebagai instrumen moneter dan fiskal yang saling bahu membahu untuk mengelola ekses likuiditas. Mengingat potensi wakaf uang di Indonesia yang cukup besar, pemerintah Indonesia telah mulai mengakomodir upaya pengembangan wakaf uang ini dengan diaturnya kebolehan penerapan wakaf uang dalam Undang-Undang Nomor 41 Tahun 2004 dan Peraturan Pemerintah Nomor 42 Tahun 2006.

Wakaf uang merupakan inovasi dalam keuangan islam (Islamic finance). Wakaf uang membuka peluang penciptaan investasi di bidang keagamaan, Pendidikan, dan pelayanan sosial. Disamping itu, wakaf uang juga berfungsi sebagai investasi yang strategis untuk menekan angka kemiskinan dan menangani ketertinggalan di bidang ekonomi, pendidikan, kesehatan, dan sebagainya.

Badan Wakaf Indonesia (BWI) menyebut potensi wakaf tunai di Tanah Air mencapai Rp 180 triliun. Dari jumlah itu sebanyak Rp 400 miliar sudah terealisasi. Sementara tahun depan, BWI menargetkan realisasi wakaf tunai mencapai Rp 800 miliar. Salah satu contoh realisasi wakaf tunai diperuntukkan membantu mahasiswa berwirausaha dan memenuhi kebutuhan sehari-hari. Program itu disebut Waini atau Wakaf Mahasiswa Indonesia.

Manajemen wakaf uang mempunyai karakteristik yang unik yang konsepnya berbeda dengan manajemen sedekah, derma, atau sumbangan dalam perspektif Barat. Wakaf mempunyai prinsip keabadian yang membuat ia berbeda dari sedekah, charity (derma). ${ }^{1}$

Wakaf uang juga dapat disalurkan untuk membantu lembaga pendidikan yang selalu kekurangan biaya operasional, yaitu melalui pemberian beasiswa kepada peserta didik dan insentif untuk pengelola sekolah. Dengan profit dari wakaf uang, dapat membantu bagi pendirian ataupun operasionalisasilembaga-lembaga

pendidikan, rumah sakit, termasuk masjid dan lembaga sosial lainnya. Dengan demikian, lembaga yang concern terhadap pengelolaan wakaf uang, kontribusi dalam mengatasi problema kemiskinan dan kebodohan yang mendera bangsa akan lebih signifikan. $^{2}$

Dinegara lain, wakaf sudah menjadi salah satu kekuatan perekonomian sudah sejak lama, Mesir misalnya. Di Mesir, wakaf dalam bidang pendidikan, Universitas alAzhar tidak diragukan dihidupi oleh wakaf. Bahkan Universitas al-Azhar menjadi salah satu contoh filantropi Islam yang memiliki harta wakaf yang sangat besar dan juga usaha-usaha lainnya. Dengan adanya dana yang sangat besar, Universitas al-Azhar sangat independen, bahkan anggaran belanja lembaga pendidikan ini melampaui anggaran belanja negara Mesir sendiri. ${ }^{3}$

Sebelas universitas dunia berkembang melalui sistem wakaf pendidikan. Yaitu Universitas Massachusetts Institute of Technology (MIT) sebesar 12 miliar dolar AS, Harvard University (35 miliar USD), University of Cambridge (5 Juta Pound

\footnotetext{
${ }^{1}$ Rozalinda, Manajemen Wakaf Produktif (Jakarta: PT RajaGrafindo Persada, 2016), xiii.

${ }^{2}$ Rozalinda, Manajemen.,356.

${ }^{3}$ Najib Ridwan dan Tuti A. al-Makassary.,Wakaf, Tuhan, dan Agenda Kemanusiaan, studi tentang wakaf dalam perspektif keadilan social di Indonesia, Center for the study of Religion and culture UIN Syarif Hidayatullah, Jakarta (2016), 58.
} 
sterling), Stanford University (21 miliar USD), California Institute of Technology (Caltech) sebesar 2 miliar USD, University of Oxford, UCL (University College London), Imperial College London, ETH Zurich Swiss Federal Institute of Technology, University of Chicago dan Princeton University.

Wakaf Amerta Airlangga adalah wakaf uang dan wakaf melalui uang yang dihimpun dari masyarakat luas (wakif) dan dikelola secara produktif dengan prinsip menjaga nilai pokoknya dan memanfaatkan hasilnya untuk memudahkan masyarakat yang membutuhkan (mauquf 'alaih) mendapatkan pendidikan yang berkualitas di Universitas Airlangga. Pusat pengelolaan dana social (PUSPAS) adalah unit kerja di lingkungan Universitas Airlangga yang bertugas menghimpun, mengelola, dan menyalurkan donasi social dari masyarakat berdasarkan keputusan Rektor Nomor 789/UN3/2017.

Badan Wakaf Indonesia (BWI) mengeluarkan surat keputusan persetujuan pengelolaan wakaf kepada UNAIR pada Kamis (23/8/2018), di Jakarta. Lebih tapatnya melalui Pusat Pengelolaan Dana Sosial (PUSPAS) UNAIR. Persetujuan tersebut menjadikan UNAIR sebagai perguruan tinggi pertama sekaligus satusatunya pengelola wakaf. BWI (Badan Wakaf Indonesia) Pusat membacakan keputusan bahwa UNAIR disetujui menjadi nazhir (pengelola wakaf) melalui PUSPAS (Pusat Pengelola Dana Sosial) UNAIR. Persetujuan tersebut menjadi dasar UNAIR diizinkan mengelola wakaf dan PUSPAS sebagai pelaksana. Dengan status baru itu, mulai saat ini UNAIR sudah langsung bisa mengelola dana wakaf yang diterima. Dengan ini UNAIR sudah bisa menerima donasi cash waqaf (wakaf uang).

Dari sinilah, penulis terdorong untuk mengadakan penelitian, pengkajian, potensi dan analisis pengembangan wakaf uang sebagai alternatif pembiayaan Pendidikan, dengan harapansemakin banyak anak bangsa yang berpendidikan berkualitas tinggi melalui Wakaf Amerta Airlangga ini.

Sesuai dengan rumusan masalah di atas, maka penelitian ini memiliki tujuan sebagai berikut :

1. Untuk mengetahui pemanfaatan wakaf tunai untuk pendidikan tinggi di Wakaf Amerta Airlangga.

2. Untuk mengetahui analisis model pengembangan wakaf tunai di Amerta Airlangga.

Gambaran tentang penelitian ini, diharapkan mampu memberikan manfaat ilmu pengetahuan terutama dalam pengembangan wakaf uang untuk Pendidikan yang meliputi :Manfaat Teoritis (Dapat menambah wacana khazanah keilmuan tentang potensi wakaf tunai untuk Pendidikan baik bagi Lembaga pendidikan, pemerintah maupun masyarakat).

Manfaat Praktis (Penelitian ini setidaknya memperkaya perbendaharaan konsep tentang wakaf produktif secara umum, dan pemanfaatan wakaf uang di bidang pendidikan. Dan Sebagai bahan kajian lebih lanjut bagi peneliti lain yang meneliti lebih lanjut tentang wakaf tunai secara lebih luas.

\section{B. LANDASAN TEORI}

Dalam sejarah Islam, Wakaf dikenal sejak masa Rasulullah SAW karena wakaf disyariatkan setelah Nabi SAW berhijrah ke Madinah, pada tahun kedua Hijriyah. Ada dua pendapat yang berkembang di kalangan ahli yurisprudensi Islam (fuqaha') tentang siapa yang pertama kali melaksanakan Syariat wakaf. Menurut sebagian pendapat ulama mengatakan bahwa yang pertama kali melaksanakan wakaf adalah Rasulullah SAW ialah wakaf tanah milik Nabi SAW untuk dibangun masjid. Pendapat ini berdasarkan hadits yang diriwayatkan oleh 
Umar bin Syabah dari 'Amr bin Sa'ad bin Mu'ad, ia berkata: Dan diriwayatkan dari Umar bin Syabah, dari Umar bin Sa'ad bin Muad berkata: "Kami bertanya tentang mula-mula wakaf dalam Islam? Orang Muhajirin mengatakan adalah wakaf Umar, sedangkan orang-orang Anshar mengatakan adalah wakaf Rasulullah SAW.Amirul Mukminin Umar bin al-Khaththab memiliki tanah di Khaibar. Tanah tersebut adalah harta paling berharga yang beliau miliki. Beliau pun datang menemui Rasulullah untuk meminta pendapat beliau tentang apa yang seharusnya dilakukan (dengan tanah tersebut), karena para sahabat adalah orangorang yang senantiasa menginfakkan harta yang paling mereka sukai. Nabi memberikan petunjuk kepada beliau untuk mewakafkannya dan mengatakan,

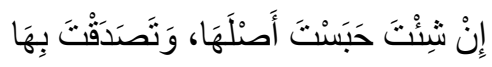

"Jika engkau mau, engkau tahan harta tersebut dan engkau sedekahkan hasilnya." (HR. Bukhari-Muslim). Ini adalah wakaf pertama dalam Islam.Cara seperti ini tidak dikenal di masa jahiliah.Rasulullah SAW pada tahun ketiga Hijriyah pernah mewakafkan tujuh kebun Kurma di Madinah; di antaranya ialah kebun A'raf, Shafiyah, Dalal, Barqah dan kebun lainnya. Menurut pendapat sebagian ulama mengatakan bahwa yang pertama kali melaksanakan Syariat wakaf adalah Umar bin Khathab.

Secara umum tidak terdapat ayat al-Quran yang menerangkan konsep wakaf secara jelas.Oleh karena wakaf termasuk infaq $f i$ sabilillah, maka dasar yang digunakan para ulama dalam menerangkan konsep wakaf ini didasarkan pada keumuman ayat-ayat alQuran yang menjelaskan tentang infaq $f i$ sabilillah. Di antara ayat-ayat tersebut antara lain:

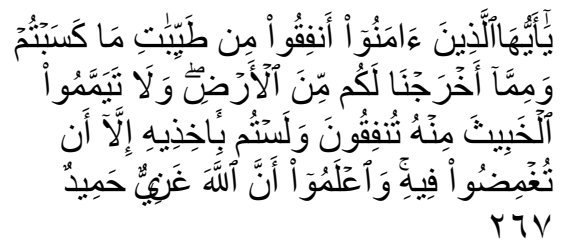

"Hai orang-orang yang beriman, nafkahkanlah (di jalan allah) sebagian dari hasil usahamu yang baik-baik dan sebagian dari apa yang Kami keluarkan dari bumi untuk kamu. Dan janganlah kamu memilih yang buruk-buruk lalu kamu menafkahkan daripadanya, padahal kamu sendiri tidak mau mengambilnya melainkan dengan memincingkan mata terhadapnya.Dan ketahuilah, bahwa Allah Maha Kaya lagi Maha Terpuji.",

Secara bahasa: menahan. Secara istilah: Menahan harta dan mengalirkan manfaatnya di jalan Allah. Wakaf itu menyempurnakan harta yang kita miliki. Kata Wakaf berasal dari bahasa Arab (waqafa - yaqifu - waqfa) yang berarti berhenti, persamaannya adalah habasa, atau (habasa - yahbisu - habsan wa mahbasa). Pada zaman Nabi saw dan para sahabat dikenal dengan istilah habs, tasbil, atau tahrim. Belakangan baru dikenal wakaf. ${ }^{5}$

Menurut Istilah Ahli Fiqih Para ahli fiqih berbeda dalam mendefinisikan wakaf menurut istilah, sehingga mereka berbeda pula dalam memandang hakikat wakaf itu sendiri. Berbagai pandangan tentang wakaf menurut istilah sebagai berikut:

\footnotetext{
${ }^{4}$ QS. al-Baqarah: 267

${ }^{5}$ Tata Fathurrohman. (2006), Wakaf dan Usaha penangulangan kemiskinan tinjauan hukum Islam dan peraturan perundang-undangan di Indonesia (Studi kasus pengelolaan Wakaf di Kabupaten Bandung), Disertasi Doktor Fakultas Hukum Universitas Indonesia, Jakarta., 34
} 
1) Abu Hanifah berpendapat wakaf adalah menahan suatu benda yang menurut hukum, tetap milik si wakif dalam rangka mempergunakan manfaatnya untuk kebajikan. Berdasarkan definisi itu maka pemilikan harta wakaf tidak lepas dari si wakif, bahkan ia dibenarkan menariknya kembali dan ia boleh menjualnya. Jika si wakif wafat, harta tersebut menjadi harta warisan buat ahli warisnya. Jadi yang timbul dari wakaf hanyalah "menyumbangkan manfaat".

2) Mazhab Maliki menyebut bahwa wakaf itu tidak melepaskan harta yang diwakafkan dari kepemilikan wakif, namun wakaf tersebut mencegah wakif melakukan tindakan yang dapat melepaskan kepemilikannya atas harta tersebut kepada yang lain dan wakif berkewajiban menyedekahkan manfaatnya serta tidak boleh menarik kembali wakafnya. Perbuatan si wakif menjadikan manfaat hartanya untuk digunakan oleh mustahiq (penerima wakaf), walaupun yang dimilikinya itu berbentuk upah, atau menjadikan hasilnya untuk dapat digunakan seperti mewakafkan uang. Wakaf dilakukan dengan mengucapkan lafadz wakaf untuk masa tertentu sesuai dengan keinginan pemilik.

3) Mazhab Syafi'i dan Ahmad bin Hambal Syafi'i dan Ahmad berpendapat bahwa wakaf adalah melepaskan harta yang diwakafkan dari kepemilikan wakif, setelah sempurna prosedur perwakafan. Wakif tidak boleh melakukan apa saja terhadap harta yang diwakafkan, seperti :perlakuan pemilik dengan cara pemilikannya kepada yang lain, baik dengan tukaran atau tidak. Jika wakif wafat, harta yang diwakafkan tersebut tidak dapat diwarisi oleh ahli warisnya.

4) Mazhab lain sama dengan mazhab ketiga, namun berbeda dari segi kepemilikan atas benda yang diwakafkan yaitu menjadi milik mauquf 'alaih (yang diberi wakaf), meskipun mauquf 'alaih tidak berhak melakukan suatu tindakan atas benda wakaf tersebut, baik menjual atau menghibahkannya. ${ }^{6}$

Di Barat kata-kata yang digunakan untuk menyatakan sejenis Wakaf dapat berupa foundation, endownment, corporation dan trust.Foundation menurut kamus Oxford adalah harta yang dikhususkan untuk kepentingan organisasi selamanya.Endowment adalah pemberian.

Menurut al-Kabisi, para ahli fikih Mazhab Syafi'i mendefinisikan Wakaf dengan beragam definisi, yang dapat diringkas sebagai berikut:

1) Imam Nawawi dari kalangan Mazhab Syafi'i, mendefinisikan Wakaf dengan "Menahan harta yang dapat diambil manfaatnya bukan untuk dirinya. Sementara benda itu tetap ada. Dan digunakan manfaatnya untuk kebaikan dan mendekatkan diri kepada Allah. Definisi ini dikutip oleh al-Munawi dalam bukunya al-Taisir.

2) Al-Syarbini al-Khatib dan Ramli alKabir mendefinisikan Wakaf dengan menahan harta yang bisa diambil manfaatnya dengan menjaga keamanan benda tersebut dan memutuskan kepemilikan barang tersebut dari pemiliknya untuk hal-hal yang dibolehkan.

3) Ibnu Hajar al-Haitami dan Syaikh Umairah mendefinisikan dengan menahan harta yang bisa dimanfaatkan dengan menjaga keutuhan harta tersebut. Dengan memutuskan kepemilikan barang tersebut dari pemiliknya untuk hal yang dibolehkan.

${ }^{6}$ Prof. Dr. Nasaruddin Umar. (2006), Fiqh Wakaf ,Kementrian Agama Republik Indonesia Direktorat Jenderal Bimbingan Masyarakat Islam Direktorat Pemberdayaan Wakaf, 1-3. 
4) Syaikh Syihabuddin al-Qalyubi mendefinisikannya dengan menahan harta untuk dimanfaatkan, dalam hal yang dibolehkan dengan menjaga keutuhan harta tersebut. Titik persamaan dari masing-masing definisi itu adalah definisi Syaikh al-Qalyubi yang mengatakan bahwa Wakaf adalah "Habsul mali yumkinu al intifa'u bihi ma'a baqa'i ainihi 'ala mashrafin mubahin (Menahan harta yang bisa disalurkan kepada jalan yang dibolehkan $)^{7}$

Wakaf Tunai (cash waqf)sudahdipraktekkan sejak awal abad kedua hijriyah. Imam az-Zuhri (wafat 124 H) salah seorang ulama terkemuka dan peletak dasar tadwin al hadits memfatwakan, dianjurkan wakaf dinar dan dirham untuk pembangunan sarana dakwah, sosial, dan pendidikan umat Islam. Adapun caranya adalah dengan menjadikan uang tersebut sebagai modal usaha kemudian menyalurkan keuntungannya sebagai wakaf.

Beberapa manfaat utama wakaf tunai antara lain adalah:

a. Seseorang yang memilki dana terbatas sudah bisa mulai memberikan dana wakafnya tanpa harus menunggu menjadi tuan tanah terlebih dahulu.

b. Melalui wakaf uang, aset-aset wakaf yang berupa tanah-tanah kosong bisa mulai dimanfaatkan dengan pembangunan gedung atau diolah untuk lahan pertanian.

c. Dana wakaf tunai juga bisa membantu sebagian lembaga-lembaga pendidikan islam.

7 Muhammad Abid Al-Kabisi, (2004), Hukum Wakaf; Kajian Kontemporer pertama dan terlengkap tentang fungsi dan pengelolaan Wakaf serta penyelesaian atas sengketa wakaf, diterbitkan bersama antara IIMaN Press dan Dompet Dhuafa Republika, Jakarta ,41. d. Umat islam dapat lebih mandiri dalam mengembangkan dunia pendidikan tanpa harus tergantung pada anggaran pendidikan negara yang memang semakin lama semakin terbatas. ${ }^{8}$

Gerakan wakaf uang Nasional yang dicanangkan Susilo Bambang Yudhoyono (2010) di era reformasi, memberikan harapan melalui wakaf uang dapat memeberikan kontribusi bagi kemaslahatan masyarakat yang lebih baik melalui kelembagaan amal keagamaan Islam di bidang wakaf uang.

Uang menempati posisi penting dalam kegiatan transaksi ekonomi di berbagai negara di dunia. Sekarang, uang tidak hanya berfungsi sebagai alat tukar, tetapi sudah diangap sebagai benda- meskipun terjadi silang pendapat diantara pakar fiqih- yang dapat diperdagangkan. Oleh karena itu, ulama di Pakistan sudah membolehkan adanya wakaf uang dengan istilah cash waqf, waqf al-nuqud yang diterjemahkan ke dalam Bahasa Indonesia menjadi wakaf tunai.

Di Indonesia, dalam hal wakaf tunai pada tanggal 11 Mei 2002 Komisi Fatwa Majelis Ulama Indonesia telah menetapkan fatwa sebagai berikut:

a) Wakaf uang (Cash Waqaf/Waqf alNuqud) adalah wakaf yang dilakukan seseorang, kelompok orang, lembaga atau badan hukum dalam bentuk uang tunai.

b) Termasuk ke dalam pengertian uang adalah surat-surat berharga.

c) Wakaf uang hukumnya jawaz (boleh).

d) Wakaf uang hanya boleh disalurkan dan digunakan untuk hal-hal yang dibolehkan secara syar'i.

e) Nilai pokok wakaf uang harus dijamin kelestariannya, tidak boleh dijual, dihibahkan, dan atau diwariskan.

\footnotetext{
${ }^{8}$ M. Rusydi, Potensi Pengembangan Wakaf Uang di Kota Palembang, (Preleminary Research) 2-3
} 
Pertimbangan fatwa MUI tentang wakaf uang adalah sebagai berikut:

a) QS. Ali Imran (3): 92 tentang perintah agar manusia menyedekahkan sebagian harta yang dicintainya.

b) QS. Al-Baqarah (2): 261-262 tentang balasan yang berlipat ganda bagi orang yang menyedekahkan hartanya di jalan Allah dengan ikhlas dan pelakunya dijamin akan terhindar dari rasa khawatir (takut) serta sedih.

c) Hadits Nabi saw yang diriwayatkan oleh Imam Muslim, al-Turmudzi, al-Nasa'I, dan Abu Daud tentang perbuatan yang senantiasa mengalir pahalanya meskipun pelakunya meninggal dunia.

d) Hadits Nabi saw yang diriwayatkan oleh Imam Bukhari, Muslim, dan yang lainnya tentang wakaf tanah yang dilakukan oleh 'Umar Ibn al-Khattab r.a.

e) Qawl (pendapat) Jabir r.a. yang menyatakan bahwa para sahabat Nabi, Saw. Mewakafkan sebagian harta yang dimilikinya.

Selanjutnya, dalam pertimbangan fatwa tentang uang juga dikutip beberapa pendapat ulama klasik yang relevan dengan wakaf uang, yaitu:

a) Pendapat Imam al-Zuhri (w.124 H) yang menyatakan bahwa mewakafkan dinar hukumnya boleh (mubah), dengan cara menjadikan dinar tersebut sebagai modal usaha kemudian keuntungannya disalurkan pada mauquf'alaih.

b) Pendapat ulama Hanafiah yang membolehkan wakaf uang dinar dan dirham sebagai pengecualian, atas dasar Istihsan bi al-Urfi berdasarkan atsar Abdullah bin Mas'ud ra: "Apa yang dipandang baik oleh kaum muslimin maka dalam pandangan Allah adalah baik, dan apa yang dipandang buruk oleh kaum muslimin maka dalam pandangan Allah pun buruk."

c) Pendapat sebagian ulama Mazhab alSyafi'I yang diceritakan oleh Abu Tsaur meriwayatkan dari Imam al-Syafi'i tentang kebolehan wakaf dinar dan dirham (uang).

Dalam rapat Komisi Fatwa MUI juga dipertimbangkan Surat Direktur Pengembangan Zakat dan Wakaf Departemen Agama RI Nomor Dt.1.III/5/BA.03.2/2772/2002 tertanggal 26 April 2002. Setelah mempertimbangkan alQuran, al-Hadits, danpendapat Ulama, akhirnya Komisi Fatwa MUI menetapkan bahwa:

a) Wakaf Uang (Cash Wakaf/Waqf alNuqud) adalah wakaf yang dilakukan seseorang, kelompok orang, lembaga atau badan hukum dalam bentuk uang tunai.

b) Termasuk ke dalam pengertian uang adalah surat-surat berharga.

c) Wakaf uang hukumnya jawaz (boleh)

d) Wakaf uang hanya boleh disalurkan dan digunakan untuk hal-hal yang dibolehkan secara syar'i.

Nilai pokok Wakaf Uang harus dijamin kelestariannya, tidak boleh dijual, dihibahkan, dan atau diwariskan.

\section{PEMBAHASAN}

Berdirinya Universitas Airlangga tahun 1954, yang selanjutnya disingkat UNAIR, tidak dapat dipisahkan dari perjalanan panjang pendidikan tinggi di Indonesia. Cikal bakal perguruan tinggi di Indonesia itu adalah "Dokter Djawa School" (Sekolah Dokter Jawa), didirikan di Batavia tahun 1851.Dalam perjalanan sejarah, lembaga itu direorganisasi menjadi School Tot Opleiding van Indische Artsen (STOVIA) tahun 1902. Sebelas tahun kemudian, berdasarkan Keputusan Pemerintah "Besluit van de Gouverneur van Netherlandsch Indie” Nomor 4211 tanggal 8 Mei 1913, didirikanlah 
Sekolah Dokter di Surabaya bernama Netherlandsch Indische Artsen School (NIAS). Berkedudukan di Jl. Kedungdoro 38 Surabaya. NIAS diresmikan tanggal 1 Juli 1913, sedangkan pendidikannya dimulai pada tanggal 15 Juli 1913. Tahun 1928 bahkan didirikan School Tot Opleiding van Indische Tandartsen (STOVIT) sebagai sekolah untuk kedokteran gigi. Pengelola Wakaf (Pusat Pengelolaan Dana Sosial/PUSPAS) Institusi pendidikan tinggi di Indonesia merupakan tempat berkumpulnya elemen masyarakat yang beragam. Pada tahun 2017, berdasarkan data Kementerian Riset, Teknologi, dan Pendidikan Tinggi (Ristek Dikti), jumlah unit perguruan tinggi yang terdaftar mencapai ,4504, unit. Angka ini didominasi oleh Perguruan Tinggi Swasta (PTS) yang mencapai 3136 unit. Sedangkan perguruan tinggi negeri (PTN) menjadi unit paling sedikit yakni 122 unit. Sisanya adalah perguruan tinggi agama dan perguruan tinggi di bawah kementerian atau lembaga negara dengan sistem kedinasan. Pengembangan potensi wakaf yang belum optimal dan termanfaatkan dengan baik, mampu diakomodasi oleh institusi pendidikan tinggi. Hal ini dikarenakan fasilitas, sarana-prasarana dan sumber daya manusia yang kompeten.

Saat ini, Universitas Airlangga merupakan universitas pertama yang menjadi Nazhir (pengelola) wakaf uang di Indonesia yang terdaftar di Badan Wakaf Indonesia (BWI) per tanggal 27 September 2018; dengan nomor registrasi 3.3.00199. Selanjutnya, pihak Universitas Airlangga menunjuk Pusat Pengelolaan Dana Sosial (PUSPAS) sebagai unit kerja yang bertugas untuk menghimpun, mengelola, dan menyalurkan donasi sosial dari masyarakat yang salah satunya adalah dana wakaf.

Penunjukan Universitas Airlangga sebagai Nazhir wakaf uang menjadi peluang untuk mengoptimalkan potensi wakaf yang selama ini masih belum berkembang dengan baik utamanya di dunia perguruan tinggi. Kesempatan untuk menggerakkan generasi muda dan mengembangkan wakaf dari dalam kampus sangat memungkinkan. Universitas Airlangga memiliki banyak keunggulan, berada di kota Surabaya yang merupakan kota terbesar kedua di Indonesia sekaligus ibukota Provinsi Jawa Timur, selain itu Universitas Airlangga memiliki jumlah mahasiswa aktif yang mencapai puluhan ribu serta alumni yang mencapai ratusan ribu tersebar di seluruh Indonesia bahkan di mancanegara, kemudian juga Universitas Airlangga memiliki jajaran pengajar yang kompeten di berbagai bidang keilmuan termasuk bidang wakaf, baik dalam level regional, nasional, maupun internasional. Selain itu, pengelolaan wakaf di Universitas Airlangga yang dijalankan oleh Pusat Pengelolaan Dana Sosial dijalankan secara profesional dengan sumber daya manusia yang kompeten di bidangnya.

Wakaf Amerta Universitas Airlangga Wakaf Amerta Universitas Airlangga adalah wakaf uang dan wakaf melalui uang yang dihimpun dari masyarakat luas (wakif) dan dikelola secara produktif dengan prinsip menjaga nilai pokoknya dan memanfaatkan hasilnya untuk diinvestasikan ke dalam sektor-sektor ekonomi yang menguntungkan dengan ketentuan persentase tertentu digunakan untuk pengembangan pendidikan di lingkungan Universitas Airlangga. Wakaf 
Amerta merupakan program wakaf yang dijalankan oleh Universitas Airlangga melalui Pusat Pengelolaan Dana Sosial (PUSPAS) yang telah ditunjuk oleh Badan Wakaf Indonesia (BWI) sebagai Nazhir wakaf uang pertama dari perguruan tinggi.

Amerta sendiri berasal dari bahasa Sansekerta yakni amrta; Devanagari. Secara etimologi berarti tidak mati atau kehidupan. Secara terminology Amerta Airlangga yang digunakan sebagai program oleh Pusat Pengelolaan Dana Sosial terinspirasi dari lambang tirta amerta yakni air suci yang dibawa oleh Garuda Mukti sebagaimana terdapat dalam logo Universitas Airlangga. Penggunaan terminology Amerta Airlangga diharapkan menjadi salah satu manifestasi dari lambang Universitas Airlangga yakni sebagai sumber ilmu abadi. ${ }^{9}$

Pusat Pengelolaan Dana Sosial (PUSPAS) adalah unit kerja di lingkungan Universitas Airlangga yang bertugas menghimpun, mengelola, dan menyalurkan donasi sosial dari masyarakat berdasarkan Surat Keputusan Rektor Nomor 789/UN3/2017.Wakaf Amerta Airlangga adalah wakaf tunai yang dihimpun dari masyarakat luas (wakif) dan dikelola secara produktif dengan prinsip menjaga nilai pokoknya dan memanfaatkan hasilnya untuk memudahkan masyarakat yang membutuhan (mauquf 'alaih) mendapatkan pendidikan yang berkualitas di Universitas Airlangga.

Model Manajemen Investasi Wakaf Uang melalui PUSPAS Airlangga ditampilkan oleh gambar berikut:

${ }^{9}$ Tika Widiastuti, Handbook Wakaf Amerta(Surabaya: Airlangga University Press, 2019.),33-34.

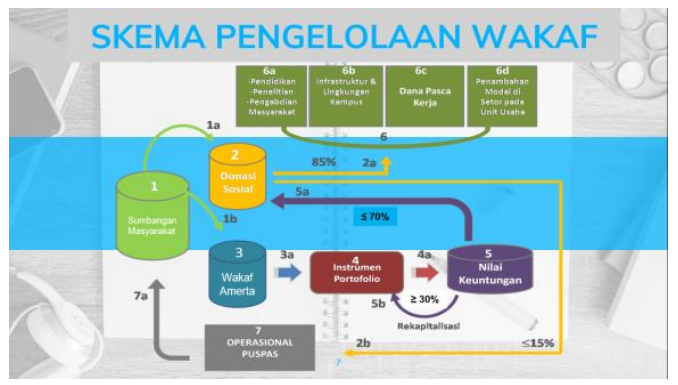

Masyarakat mendonasikan dananya kepada PUSPAS Universitas Airlangga yang terbagi atas dua jenis, yakni donasi sosial non-wakaf dan donasi wakaf. Kemudian sebagian dana non-wakaf langsung dimasukkan ke rekening donasi sosial yang dapat langsung dimanfaatkan untuk program PUSPAS Universitas Airlangga, sebesar $85 \%$. Sementara $15 \%$ lainnya untuk operasional PUSPAS Universitas Airlangga.Dana Wakaf Uang melalui program Wakaf Amerta akan dikelola secara tersendiri pokok dananya sebagai investasi pada sejumlah portofolio."10

Instrumen portofolio yang menjadi tujuan investasi PUSPAS Universitas Airlangga adalah sebagai berikut:

1) Aset Keuangan, yang dikelola oleh Profesional Asset Management, mencakup: Deposito Syariah; Sukuk Negara; Sukuk Link Wakaf (Kemenkeu); Reksadana Syariah; Saham Syariah.

2) Aset Berwujud dan Tidak Berwujud, berupa penyertaan investasi yang dikelola oleh Airlangga Holding Company, mencakup Properti; Kendaraan; Mesin/Peralatan; dan HakCipta/Paten

3) Keuntungan yang didapatkan dari investasi portofolio, sekitar $70 \%$ akan masuk ke rekening donasi sosial yang digunakan untuk membiayai program

\footnotetext{
${ }^{10}$ Tika Widiastuti, Wawancara, Surabaya, 4 Oktober
} 
PUSPAS Airlangga, sementara 30\% akan diinvestasikan kembali dalam bentuk portofolio.

4) Cakupan program PUSPAS Universitas Airlangga:

a) Program Universitas Airlangga, baik pada aspek Pendidikan, Penelitian maupun Pengabdian Masyarakat

b) Peningkatan infrastruktur dan fasilitas di Universitas Airlangga

c) Dana pasca kerja

d) Penambahan modal pada unit usaha. Operasional PUSPAS utamanya ditujukan untuk meningkatkan penerimaan sumbangan dari masyarakat.

Aset Keuangan (dikelola oleh Profesional Asset Management):

1) Deposito Syariah

2) Sukuk Negara

3) Sukuk Link Wakaf (Kemenkeu)

4) Reksadana Syariah

5) Saham Syariah

Aset Berwujud dan Tidak Berwujud (penyertaan investasi yang dikelola oleh Airlangga Holding Company):

1) Properti

2) Kendaraan

3) Mesin/Peralatan

4) Hak Cipta/Paten

Kenapa wakaf yang menjadi objek penelitian ini, bukan zakat, sedekah, infaq, dan lain-lain. Maka perlu diurai keistimewaan wakaf khususnya wakaf Amerta Airlangga, sebagai berikut:

\section{a. Pahalanya terus mengalir sekalipun yang berwakaf sudah meninggal.}

Didasarkan pada hadits Nabi saw: "Jika manusia mati, terputuslah amalnya kecuali tiga: sedekah jariah, ilmu yang dimanfaatkan, atau anak salih yang mendoakannya". (HR Muslim, Abu Dawud, at-Tirmidzi, an-Nasa'i dan Ahmad). Imam al-Nawawi, dalam Syarh Shahih Muslim menjelaskan hadits di atas sebagai berikut: "Para ulama menyatakan, amal perbuatan orang yang telah meninggal dunia terputus dengan kematiannya kecuali tiga hal ini. Sebab, tiga perkara tersebut berasal dari usaha orang yang telah meninggal itu.

Sesungguhnya anak shaleh termasuk hasil usahanya; demikian pula dengan ilmunya yang terus diajarkan atau dikaji setelah kematiannya; dan sedekah jariyah, yakni wakaf. Pahala doa akan sampai kepada orang yang mati, demikian juga dengan pahala sedekah.

\section{b. UNAIR jadi Universitas Pertama yang kelola Dana Wakaf.}

Universitas Airlangga kembali membukukan sejarah. Badan Wakaf Indonesia (BWI) mengeluarkan surat keputusan persetujuan pengelolaan wakaf kepada UNAIR pada Kamis (23/8/2018) di Jakarta. Lebih tapatnya melalui Pusat Pengelolaan Dana Sosial (PUSPAS) UNAIR. Persetujuan tersebut menjadikan UNAIR sebagai perguruan tinggi pertama sekaligus satu-satunya pengelola wakaf. BWI Pusat membacakan keputusan bahwa UNAIR disetujui menjadi nazhir (pengelola wakaf) melalui PUSPAS (Pusat Pengelola Dana Sosial) UNAIR. Persetujuan tersebut menjadi dasar UNAIR diizinkan mengelola wakaf dan PUSPAS sebagai pelaksana.

Dengan keputusan itu, UNAIR secara sah dan berkuatan hukum menjadi perguruan tinggi pertama yang disetujui menjadi Nazhir Wakaf atau pengelola wakaf. Capaian itu menjadi sangat istimewa. Mengingat, itu yang belum dicapai Univeitas Indonesia (UI), Institut Teknologi Bandung (ITB), maupun Universitas Gadjah Mada (UGM). Termasuk kampus-kampus yang lain. Dengan status baru tersebut, mulai saat ini UNAIR sudah langsung bisa mengelola dana wakaf yang diterima. 
Dengan ini UNAIR sudah bisa menerima donasi cash waqf (wakaf uang),.

\section{c. Bisa wakaf hanya dengan seribu rupiah.}

Apa itu Gebu? Gerakan Wakaf Seribu (disingkat GEBU) adalah sebuah gerakan ajakan kepada masyarakat untuk berwakaf. Pemberi wakaf (wakif) tidak hanya mencakup civitas akademika UNAIR saja, namun juga unsur masyarakat lainnya baik sebagai individu, organisasi dan/atau perusahaan.Gerakan Wakaf Seribu (GEBU) Saat ini di Pusat Pengelolaan Dana Sosial mempunyai sebuah program bernama Gerakan Wakaf Seribu (disingkat GEBU). Gerakan Wakaf Seribu (GEBU) adalah sebuah gerakan ajakan untuk berwakaf yang ditujukan khususnya kepada civitas akademika Universitas Airlangga dan umumnya masyarakat lainnya baik sebagai individu, organisasi dan/ atau perusahaan. Adapun harta yang dapat diwakafkan dapat berupa uang tunai atau yang setara seperti logam mulia dan surat berharga yang menjadi milik penuh wakif (orang yang berwakaf). Wakif dapat mewakafkan hartanya secara seterusnya (permanen) maupun dalam jangka waktu tertentu (temporer). Adapun untuk penerima manfaat dari wakaf ini adalah mahasiswa, tenaga kependidikan, dosen, dan masyarakat di sekitar lingkungan Universitas Airlangga yang diwujudkan dalam bentuk beasiswa, bantuan penelitian, pengembangan kompetensi dan softskill, pengadaan peralatan laboratorium, bantuan kesehatan, dan pengembangan infrastruktur pendidikan.

D. Di antara keistimewaan wakaf adalah terus menerusnya manfaat hingga generasi yang akan datang tanpa mengurangi hak atau merugikan generasi sebelumnya.
Demikian pula, wakif akan mendapat pahala yang terus menerus dan berlipatlipat. Oleh karena itu, kita dapatkan para sahabat adalah orang-orang yang sangat bersemangat mewakafkan hartanya. Kita bisa melihat bagaimana sahabat Umar bin al-Khaththab, sebagaimana dalam dijelaskan dalam hadits. Umar bin alKhathtab memiliki tanah yang sangat bernilai bagi beliau karena hasil dan manfaatnya yang begitu besar. Namun, beliau menginginkan harta itu untuk akhiratnya. Beliau menghadap Nabi untuk meminta petunjuk tentang hal tersebut.Nabi menyarankan agar Umar menyedekahkannya. Sedekah tanpa dijual, ditukar, atau dipindah, yaitu dengan memanfaatkan tanah tersebut dan hasilnya disedekahkan untuk fakir miskin dan yang lainnya, sedangkan tanahnya ditahan.Tanah itu tidak bisa diambil lagi oleh pemiliknya, tidak boleh dibagikan untuk ahli warisnya, serta tidak boleh dijual dan dihibahkan. Termasuk wakaf yang dilakukan oleh para sahabat adalah apa yang disebutkan oleh sahabat Utsman bin 'Affan. Ketika Nabi datang di kota Madinah dan tidak menjumpai air yang enak rasanya selain air sumur yang dinamai Rumah, beliau bersabda: "Tidaklah orang yang mau membeli sumur Rumah kemudian dia menjadikan embernya bersama ember kaum muslimin (yaitu menjadikannya sebagai wakaf dan dia tetap bisa mengambil air darinya) itu akan mendapat balasan lebih baik dari sumber tersebut di surga.'Utsman mengatakan, "Aku pun membelinya dari harta pribadiku." (HR. at-Tirmidzi dan dinyatakan hasan oleh asy Syaikh alAlbani). Bahkan, sahabat Jabir sebagaimana dinukilkan dalam kitab al-Mughni mengatakan "Tidak ada seorang pun di antara para sahabat Nabi yang memiliki 
kemampuan (untuk berwakaf) melainkan dia akan mengeluarkan hartanya untuk wakaf." Rasulullah.Beliau adalah suri teladan dalam seluruh kebaikan, termasuk wakaf. Sahabat 'Amr ibn al-Harits mengatakan,"Setelah Rasulullah wafat, beliau tidak meninggalkan dirham, dinar, dan budak lelaki atau perempuan. Beliau hanya meninggalkan seekor bighal (yang diberi nama) al-Baidha', senjata, dan tanah yang telah beliau jadikan sebagai sedekah." (HR. al-Bukhari).Al-Imam Ibnu Hajar dalam Fathul Bari menjelaskan riwayat ini, "Beliau menyedekahkan manfaat dari tanahnya. Hukumnya adalah hukum wakaf.

\section{d. Wakaf mempunyai watak Abadi Watak wakaf adalah abadi.}

Maknanya, wakaf tidak akan habis sampai hari kiamat, ketika umat berwakaf, maka nazhir (pengelola) mempunyai kewajiban untuk menjaga wakaf tersebut dari masa ke masa, artinya wakaf tidak akan berkurang, malah dari masa ke masa terus bertambah. Jika UNAIR mampu mengumpulkan wakaf dana abadi pendidikan sebesar Rp, 1,8 M pertahun, maka jumlah tersebut akan terus berputar seperti bola salju yang terus menerus membesar. Dan dikelola dengan amanah maka manfaatnyapun akan terus berputar seperti bola salju yang terus berputar membesar. Perlu diperbanyak yang menjadikan wakaf secara produktif Pengelolaan wakaf di Indonesia, masih berupa pengelolaan tanah, masjid, kuburan, madrasah, sekolah, pondok pesantren, yang belum dikelola maksimal. Terbukti menjadi solusi, termasuk bidang pendidikan dan jaminan social. Universitas Al-Azhar Mesir menjadi contoh nyata wakaf memberikan kontribusi nyata dan solutif dalam pengelolaan wakaf produktif, dan ternyata juga diikuti oleh kampus-kampus besar di dunia. Lantas tidak ada alasan yang memadai jika kampuskampus dan lembaga pendidikan di Indonesia menolak sistim wakaf dalam pengelolaan pendidikan. Bisa jadi belum maksimalnya pengelolaan sistim wakaf pada pendidikan di Indonesia, karena minimnya edukasi sistim wakaf dan dampaknya dalam sistim pendidikan di kampus, jika sosialisasi terus digencarkan, workshop diadakan, semoga melahirkan pemahaman yang baik tentang wakaf, yang melahirkan amal nyata kegiatan wakaf.

\section{e. Pengelolaan Wakaf adalah bagian dari manajemen strategis suatu kampus.}

Data menunjukan bahwa jumlah mahasiswa UNAIR dari tahun ketahun mengalami peningkatan yang sangat baik. Pemikir strategis tidak langsung bahagia, karena disaat meningkat itu pulalah seorang pemimpin strategis memikirkan saat-saat jika jumlah mahasiswa mengalami penurunan, sementara saat jumlah mahasiswa meningkat pembangunan sarana prasarana ditingkatkan, implikasinya adalah biaya operasional yang terus meningkat drastis. Bayangkan biaya-biaya terus meningkat suatu hari jumlah mahasiswa menurun. Yang terjadi adalah biaya terus meningkat pendapatan turun, saat itu adalah masa sulit pengelolaan kampus. Diperparah lagi, bahwasanya sumber pendapatan utama kampus adalah dari mahasiswa. Pengelolaan Wakaf produktif berbentuk uang, merupakan sistim yang telah disediakan Allah untuk mengantisipasi kondisi tersebut, yaitu sistim yang mengokohkan kemandirian dan idealism kampus. Jika wakaf produktif melalui badan wakaf kampus dikelola dengan baik, maka kemandirian keuangan untuk jangka panjang akan terjaga. Saat yang sama, ketika wakaf uang sudah dimulai, bersamaan akan muncul wakafwakaf benda bergerak dan wakaf benda tidak bergerak lainnya, yang menjadi objek pengelolaan selanjutnya, dan tinggal 
mengkombinasikan dengan penghimpunan dan pegelolaan wakaf uang.

Fleksibel Di Indonesia wakaf uang telah diatur dalam fatwa Majlis Ulama Indonesia (MUI) tanggal 11 Mei 2002.

Isi dari Fatwa MUI adalah sebagai berikut:

a. Wakaf uang (cash wakaf/waqf al-Nuqud) adalah wakaf yang dilakukan seseorang, kelompok orang, lembaga atau badan hukum dalam bentuk uang tunai

b. Termasuk ke dalam pengertian uang adalah surat-surat berharga

c. Wakaf uang hukumnya jawaz (boleh)

d. Wakaf uang hanya boleh disalurkan dan digunakan untuk hal-hal yang dibolehkan secara syar' $i$

e. Nilai pokok wakaf uang harus dijamin kelestariannya, tidak boleh dijual, dihibahkan, dan atau diwariskan. Kemudian dinyatakan dengan jelas dalam pasal 3 ayat 1 UU Nomor 41 Tahun 2004 tentang wakaf, bahwa benda bergerak yang menjadi objek wakaf adalah harta benda yang tidak bisa habis karena dikonsumsi, meliputi:
a) uang,
b) logam mulia;
c) surat berharga;
d) kendaraan;
e) hak atas kekayaan intelektual;
f) hak sewa; dan benda bergerak lain sesuai dengan ketentuan syariah dan peraturan perundang-undangan yang berlaku.

Dengan demikian keistimewaan wakaf dalam hal ini adalah wakaf uang adalah fleksibel dari jumlah, tempat dan masa.Artinya tidak menunggu wakif (pemberi wakaf) mempunyai tanah dahulu, mempunyai bangunan dahulu, menjadi kaya dahulu, berapapun kekayaan yang dimiliki jika pemahaman wakaf sudah baik, maka tidak halangan bagia siapapun untuk berwakaf.

Saat ini Universitas Airlangga (Unair) sudah berumur 65 tahun, masa yang sangat matang dalam organisasi, Unair sedang berada pada masa jumlah mahasiswa yang sangat bagus, sekitar 39.414 (Data per 18 September 2017) mahasiswa/i yang sekarang kuliah aktif di Unair, dan terus bertambah banyak setiap tahaunnya. Saat yang sama Unair terus mengembangkan sarana dan prasarana, baik berupa gedung maupun lainnya, serta SDM yang semakin banyak dosen yang telah lulus S3, atau sedang pendidikan S3. Bahkan sampai saat ini memiliki 14 Fakultas dan 168 Program Studi.

Wakaf mempunyai watak Abadi Watak wakaf adalah abadi, maknanya wakaf tidak akan habis sampai hari kiamat, ketika umat berwakaf, maka nazhir (pengelola) mempunyai kewajiban untuk menjaga wakaf tersebut dari masa ke masa, artinya wakaf tidak akan berkurang, malah dari masa ke masa terus bertambah. Jika Unair melalui PUSPAS mampu mengumpulkan dana abadi sebesar Rp, 1,8M pertahun, maka jumlah tersebut akan terus berputar seperti bola salju yang terus menerus membesar. Dan dikelola dengan amanah maka manfaatnyapun akan terus berputar seperti bola salju yang terus berputar membesar. Terbukti PUSPAS Unair perolehan dana sampai tahun 2018 berhasil menggalang dana sebesar Rp. 1.402.964.736 yang berasal dari donasi umum, Rp. 5.630.000 (Zakat), Rp. 67.004.380 (Bencana), Rp. 314.477.879 (Wakaf), dan Rp. 6.208.840 (Bagi Hasil). Sehingga total perolehan dana sebesar Rp. 1.796.285.835 yang dihimpun dari 2.356 donatur. 

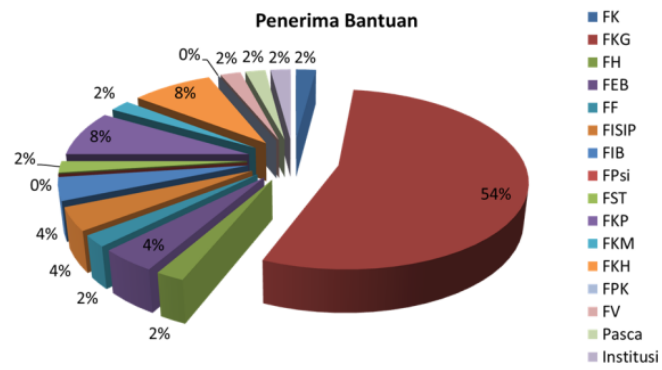

\section{KESIMPULAN}

Berdasarkan hasil penelitian dan pembahasan dapat disimpulkan sebagai berikut :

1. Dana Wakaf tunai melalui wakaf Uang melalui program Wakaf Amerta dikelola secara tersendiri pokok dananya sebagai investasi pada sejumlah portofolio. Instrumen portofolio yang menjadi tujuan investasi PUSPAS Universitas Airlangga adalah sebagai berikut: a) Aset Keuangan, yang dikelola oleh Profesional Asset Management, mencakup: Deposito Syariah; Sukuk Negara; Sukuk Link Wakaf (Kemenkeu); Reksadana Syariah; Saham Syariah b) Aset Berwujud dan Tidak Berwujud, berupa penyertaan investasi yang dikelola oleh Airlangga Holding Company, mencakup Properti; Kendaraan; Mesin/Peralatan; dan HakCipta/Paten.

2. Keuntungan yang didapatkan dari investasi portofolio, sekitar $70 \%$ akan masuk ke rekening donasi sosial yang digunakan untuk membiayai program PUSPAS Airlangga, sementara $30 \%$ akan diinvestasikan kembali dalam bentuk portofolio. Harta yang dapat diwakafkan dapat berupa uang tunai

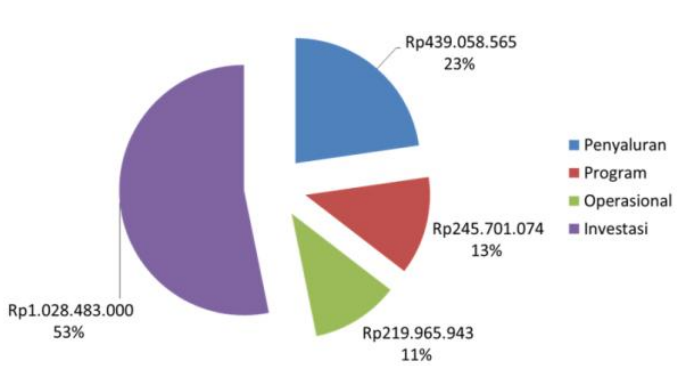

atau yang setara seperti logam mulia dan surat berharga yang menjadi milik penuh wakif (orang yang berwakaf). Wakif dapat mewakafkan hartanya secara seterusnya (permanen) maupun dalam jangka waktu tertentu (temporer). Adapun untuk penerima manfaat dari wakaf ini adalah mahasiswa, tenaga kependidikan, dosen, dan masyarakat di sekitar lingkungan Universitas Airlangga yang diwujudkan dalam bentuk beasiswa, bantuan penelitian, pengembangan kompetensi dan soft skill, pengadaan peralatan laboratorium, bantuan kesehatan, dan pengembangan infrastruktur pendidikan.

Berdasarkan hasil penelitian diatas, peneliti memberikan saran sebagai berikut:

1. Semoga penelitian ini sampai kepada pihak pengambil keputusan di tingkat fakultas dan universitas, sehingga potensi ini tidak menganggur dan terabaikaan.

2. Diperlukan penelitian selanjutnya yang lebih detail terhadap persepsi dan tingkat pemahaman pimpinan dan civitas akademika Universitas Airlangga terhadap wakaf tunai. 


\section{DAFTAR PUSTAKA}

Al-Qur'anul Karim dan Terjemah, (2009), Pustaka Al Kautsar, Jakarta

Ali, Mohammad Daud. (1988), Sistem Ekonomi Islam Zakat dan Wakaf, Universitas Indonesia Press, Jakarta.

Ali, Zainuddin. (2009), Metode Penelitian Hukum, Sinar Grafika, Jakarta.

Al-Kabisi, Muhammad Abid. (2004), Hukum Wakaf; Kajian Kontemporer pertama dan terlengkap tentang fungsi dan pengelolaan Wakaf serta penyelesaian atas sengketa wakaf, diterbitkan bersama antara IIMaN Press dan Dompet Dhuafa Republika, Jakarta

As-Syaukani.(1993), Terjemahan Nailul Author, Himpunan hadis-hadis hukum Jilid 5, Bina Ilmu, Surabaya.

Qahaf, Monzher. (2005), Manajemen Wakaf Produktif, Khalifa, Jakarta

Sabiq, Sayyid. (1986), Fikih Sunnah, Buku 14, Al Ma'arif, Bandung.

Sekaran, Uma. (2003), Research Methods for Bussiness, John Willey \& Sons, Inc., USA.

Soekanto, Soerjono. Mamudji, Sri. (2010), Penelitian Hukum Normatif, suatu tinjauan singkat, Rajawali Pers, Jakarta.

Soekanto, Soerjono. (2010), Pengantar Penelitian Hukum, UI Press, Jakarta. Nafis, M Cholil. (2011), Aplikasi wakaf uang di Indonesia, awqaf volume IV, No. 02, Juli 2011, Jakarta

Najib,Tuti A. Al-Makasary, Ridwan. (2006), Wakaf, Tuhan, dan Agenda Kemanusiaan, studi tentang wakaf dalam perspektif Keadilan sosial di Indonesia, Center for the study of religion and culture UIN Syarif Hidayatullah, Jakarta.

Fathurrohman, Tata. (2006), Wakaf dan Usaha penangulangan kemiskinan tinjauan hukum Islam dan peraturan

IKRAITH-HUMANIORA, Vol. 2, No. 2, MARET 2018 perundang-undangan di Indonesia (Studi kasus pengelolaan Wakaf di Kabupaten Bandung), Disertasi Doktor Fakultas Hukum Universitas Indonesia, Jakarta

Hasanah, Uswatun. (1997), Peranan Wakaf dalam mewujudkan kesejahteraan Sosial (Studi kasus Pengelolaan Wakaf di Jakarta Selatan). Disertasi Doktor Institut Agama Islam Negeri (IAIN) Syarif Hidyatullah, Jakarta.

Hidayat, Nuryana. (2008), Perbandingan kinerja reksa dana syariah dengan reksa dana konvensional, periode juni 2005 hingga juni 2007, Tesis di Progam Magister Ilmu Ekonomi, Universitas Trisakti.

Gunawan, D. (2003), Kajian tentang pengelolaan harta wakaf di Muhammadiyah kota Malang cabang Lowokwaru dan Cabang Klojen, skripsi ,Fakultas Tarbiyah, Universitas Muhamadiyah Malang,

Siswantoro, Dodik. (2016), Rekontruksi Akuntabilitas Lembaga Wakaf Tunai di Indonesia, Ringkasan Disertasi, FISIP, UI 
Suhartini, Yoyok. (2006), Pengelolaan dana wakaf tunai menurut Undang-Undang Nomor 41 tahun 2004, di badan wakaf Universitas Islam Indonesia, skripsi di jurusan Ekonomi dan Keuangan Syariah, STAIN, Surakarta.

http://khazanah.republika.co.id

https://news.detik.com/berita/3613732/bonusuang-jutaan-untuk-jemaah-aceh-dariwakaf-200-tahun-silam, dilihat 25 Agustus 2017, pukul 11.02 WIB 